\title{
THE PEOPLING OF AMERICA
}

\author{
Aborigines Represent the Yellow-brown Race of Asia and Polynesia-Arrived \\ on This Continent in Relatively Recent Period-Characteristics \\ of the Stock. ${ }^{1}$
}

Dr. Ales Hrdlicka, Curator, Division of Physical Anthropology, National Museum, Washington, D. C.

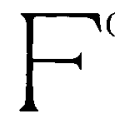

OR the American anthropologist no subject is of more interest than that of the racial affinity and the place or places of origin of the American aborigines. Ever since the discovery of the new continent and its peoples these questions have occupied many minds, but have not as yet been brought to the point of final answer. Numerous opinions were advanced, but thcy were almost wholly the results of spcculation, fettered on one side by lack of scientific research and on the other by various traditions.

When Columbus discovered the New World he and his companions imagined, as is well known, that they had reached the Indies, and the people met were naturally taken for natives of those regions. Later, as the trie nature of the new land became better known, speculation concerning the newly discovered race took other directions, and some of the notions developed proved disastrous to the Indians. History tells us that many of the early Spaniards, up to Las Casas' time, reached the conclusion that, as no mention was made concerning the American people in Hebrew traditions, they could not strictly be regarded as men equivalent to those named in biblical accounts, and this view, before being counteracted, led directly or indirectly to much enslavement and destruction of the native Americans.

Later, the origin of the Indians was sought in other parts of the world, and the seeming necessity of harmonizing this origin with biblical knowledge led to many curious opinions. ${ }^{2}$ One of these, held by Gomara, Lerius, and Lescarbot, was to the effect that the American aborigines were the descendants of the Canaanites who were expelled from their original abode by Joshua; another, held especially by McIntosh, ${ }^{3}$ that they were descended from Asiatics who themselves originated from Magog, the second son of Japhet; but the most widespread theory, and one, the remnant of which we meet to this day, was that the American Indians represented the so-called Lost Tribes of Israel. $^{4}$

\section{MORE RATIONAL IDEAS.}

During the course of the nineteenth century, with Levegue, Humboldt, ${ }^{\mathrm{s}}$ McCullogh, ${ }^{6}$ Morton, ${ }^{7}$ and especially Quatrefages, ${ }^{8}$ we begin to encounter more rational hypotheses concerning the Indians, although by no means a single opinion. Lord Kaimes, Morton,

${ }^{1}$ Extract from the proceedings of the Eighteenth International Congress of Americanists. The photographs of Asiatic types were furnished by Dr. Hrdlicka, the photographs of American rypes by the Smithsonian Institution, Bureau of American Ethnology.

See Garcia Clavigero and the nlder American historians.

3 McIntosh, J.. "Origin of the North American Indians," New York, 1843.

4Adair, J." "History of the North American Indians," London, 1775.

5 Humboldt, "Political Essay," I, p. 115; Humboldt and Bonpland, "Voyage, Vues des Cordillères," Paris, 1810.

- McCullogh, "Researches, Philosophical and Antiquuarian, Concerning the Aboriginal History of America," Baltimore. 1829.

7 Morton, S. G., "Distinctive Characteristics of the Aboriginal Race of America," 2nd ed., pp. 35-36, Philadelphia, 1844. (Also his "Crania Americana" and "Origin of the Human Species.")

8 Quatrefages, "Histoire générale des races humaines," Paris, 1887. 


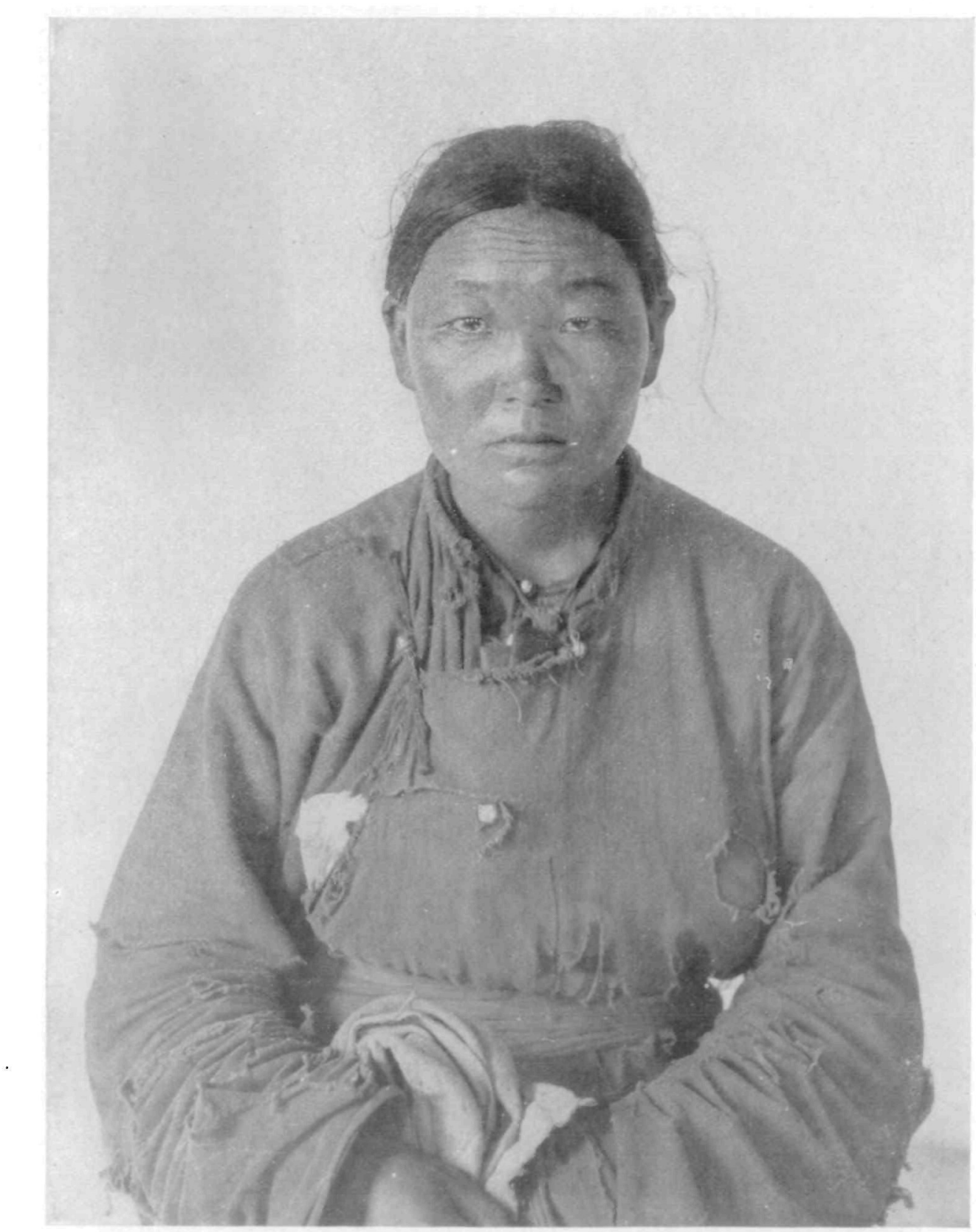

MONGOLIAN WOMAN AT URGA

If dressed in the clothes of the American Indian she could not be distinguished from a native of the New World, according to Dr. Hrdlicka. Urga is the capital of Outer Mongolia. (Fig. 14.) 


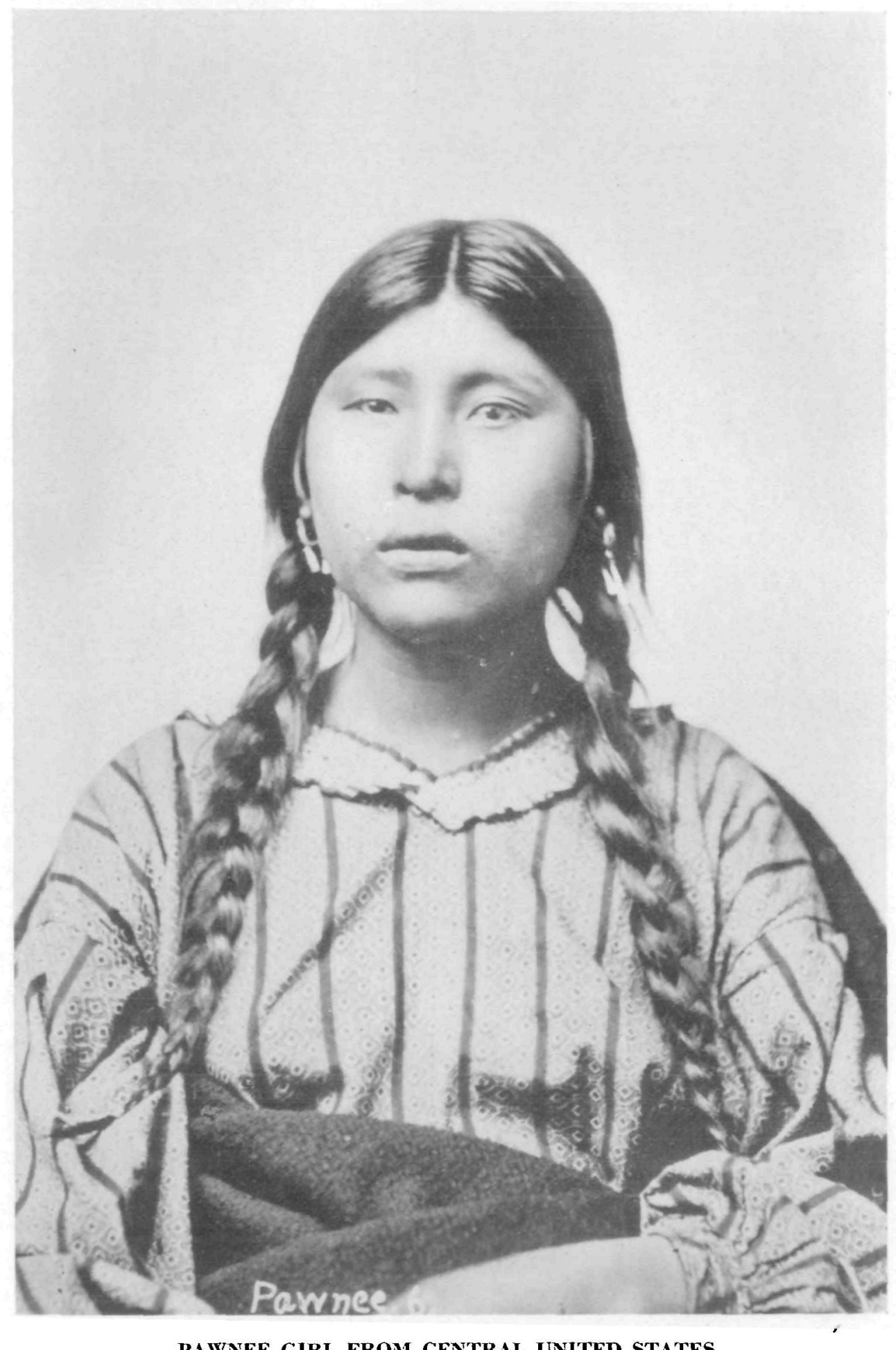

PAWNEE GIRL FROM CENTRAL UNITED STATES

The slight upward slant of the eye-slit, and the characteristic conformation of the upper lid at the inner corner of the eye, both usually supposed to be characteristic of the Mongolians, are in reality equally common among the American Indians. The "white of the eye" is yellowish, again as in the Mongolian race. (Fig. 15.) 
and Nott and Gliddon ${ }^{9}$ professed the belief that the American natives originated in the new world and hence were truly autochthonous; Grotius believed that Yucatan had been peopled by early Christian Ethiopians; according to Mitchell the ancestors of the Indians came to this country partly from the Pacific Ocean and partly from northeastern Asia; the erudite Dr. McCullogh believed that the Indians originated from parts of different peoples who reached America over lost land from the west "when the surface of the earth allowed a free transit for quadrupeds." Quatrefages viewed the Americans as a conglomerate people, resulting from the fossil race of Lagoa Santa, the race of Parana, and probably others, in addition to which he believed there had been settlements of Polynesians; and Pickering thought that the Indians originated partly from the Mongolian and partly from the Malay.

The majority of the authors of the last century, however, including Humboldt, Brerewood, Bell, Swinton, Jefferson, Latham, Quatrefages, and Peschel, ${ }^{10}$ inclined to the belief that all the American natives, excepting the Eskimo, were of one and the same race and that they were the descendants of immigrants from North-eastern Asia, particularly of the "Tartars" or Mongolians.

The most recent writers, with one marked exception, agree entirely that this country was peopled through immigration and local multiplication of people; but the locality, nature, and time of the immigration are still much mooted questions. Some authors incline to the exclusively north-eastern Asiatic origin; others, such as Ten Kate and Rivet, show a tendency to follow Quatrefages in attributing at least some parts of the native American population to the Polynesians; Brinton " held that they came in ancient times over a land connection from Europe; and Kollmann, ${ }^{12}$ basing his belief on some small crania, believes that a dwarf race preceded the Indian in America.

\section{AMEGHINO'S HYPOTHESIS.}

A remarkable hypothesis conccrning the origin of the American native population, deserving a few words apart, has within the last 30 years, and especially since the beginning of this century, been built up by Ameghino, ${ }^{13}$ the South American paleontologist. This hypothesis is, in brief, that man-not merely the American race, but mankind - originated in South America; that the early man became differentiated in the southern continent into a number of species, most of which eventually became extinct; that from South America his ancestors migrated over ancient land connections to Africa, and from there peopled, in the form of Homo ater, the larger parts of the African continent and Oceania; that a strain multiplied and spread over South America, and somewhere in the second half of the Pliocene migrated to North America and that from North America man went to Asia and Europe, where he gave rise to the Homo mongolicus and Homo cancasicus.

In addition there have been some suggestions that the Americans may have arrived from the "lost Atlantis;" and the theory has even been expressed that man, instead of migrating from north-eastern Asia into America, may have moved in the opposite direction, and especially that, after peopling this continent, a part of the Americans reached Sibcria. ${ }^{14}$

\footnotetext{
' Nott and Gliddon, "Types of Mankind, and Indigenous Races." (The latter includes statements by Leidy and Morton.)

${ }^{10}$ Peschel, O., "The Races of Mar.," p. 418, 1876.

1 Brinton, D. G., "The American Race," New York, 1891.

12 Knllmann, J., "Die Pygmäen" (Verh. d. Naturforsch, Ges. Basel, xvi, Basel, 1902).

"3 Ameghino, F., "El Tetraprothomo Argentinus" (Anal. Mus. Nac. xvi, Buenos Aires, 1907); also "Le Diprothomo platensis" (ibid., xix, 1909).

14 In this connection see also Campbell, J., "Asiatic Tribes in North America," Proc. Canadian Inst., N. S., i, Toronto, 1881; Mason, O. T., "Migration and the Food Quest; a Study in the Pcopling of America," Smithsonian Report for 1894, Washington, 1896, pp. 523-.540: Morse, E. S., "Was Middle America Peopled from Asia?" Popular Sci. Mo., November, 1898; Powcll, J. W., "Whence Came the American Indians?" Forum, February, 1898; "Major Powell's Inquiry, 'Whence Came the American Indian?' An Answer,' by J. Wickersham, Tacona, Washington
} 


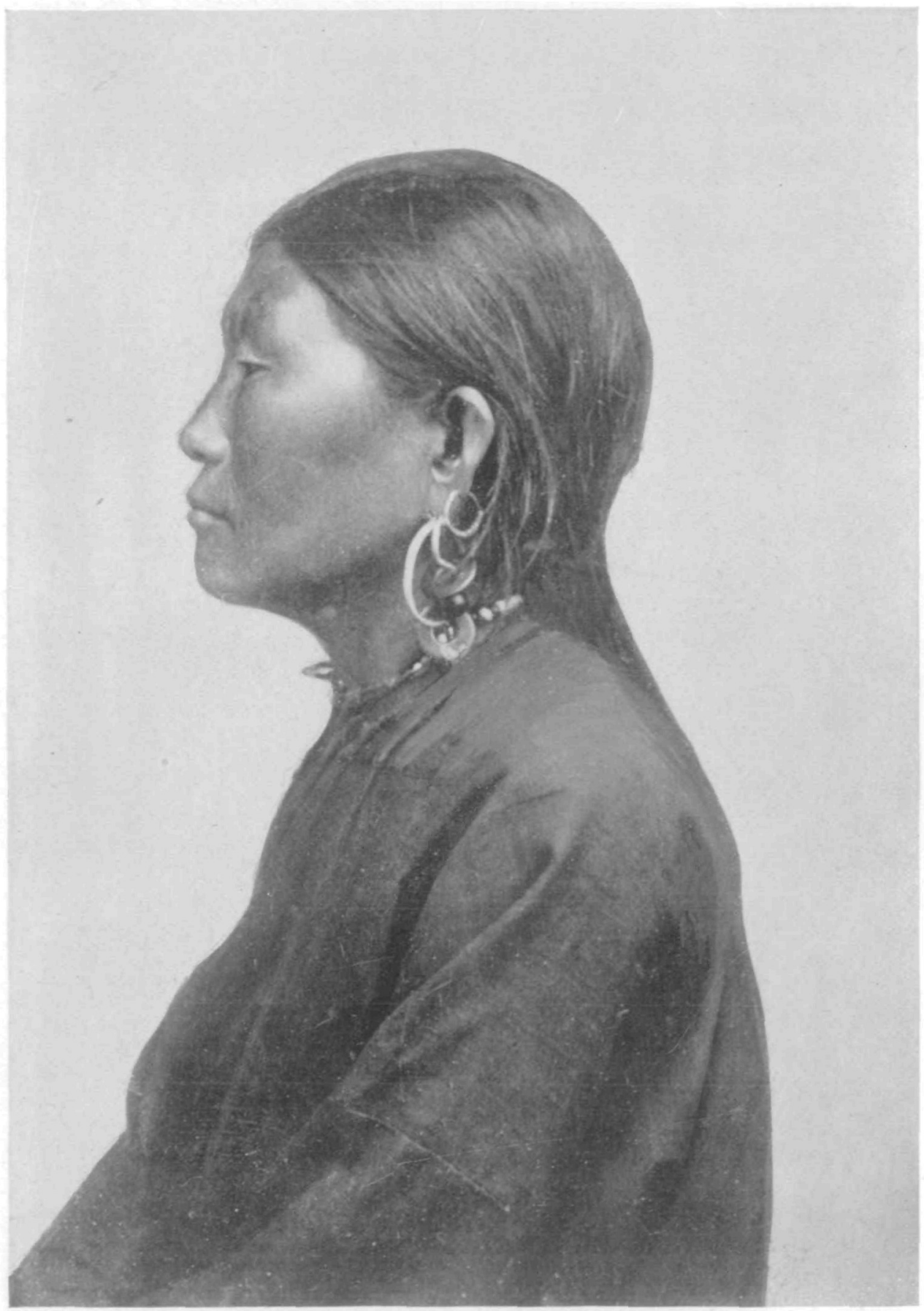

\section{GILIAK WOMAN FROM ISLAND OF SAKHALIN}

Many of the women of this part of Asia. "individually less modified by environment than the men, if introduced among the Indians and dressed to correspond, could by no means at the disposal of the anthropologist be distinguished apart," says Dr. Hrdlicka. (Fig. 16.) 


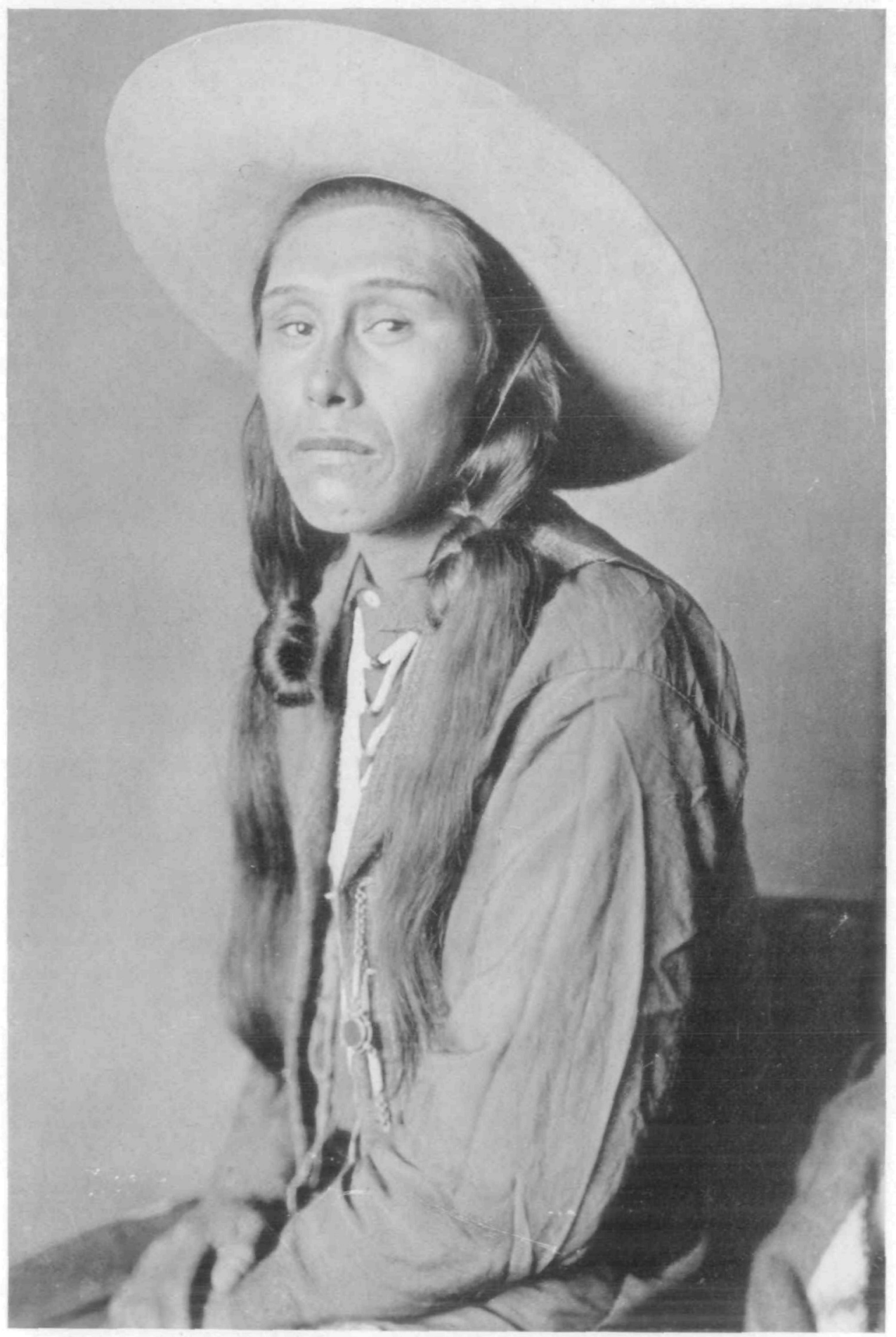

YAKIMA INDIAN, SHAHAPTIAY STOCK

The habitat of this tribe is in the extreme northwest United States and British Columbia. The broad face, well developed chin and large mouth with slightly full lips are highly characteristic of the yellow-brown race, whether it be studied in Asia or America. (Fig. 17.) 
The Eskimo have been generally considered as apart from the Indian, some holding that they preceded and others that they followed him. They have been connected generally with the north-eastern Asiatics, but there are also those who see a close original relation between the Eskimo and the Lapps, and even between the Eskimo and the Paleolithic Europeans.

These are, in brief, the various more or less speculative opinions that so far have been advanced in an effort to explain the ethnic identity and the place of origin of the American Indian; and it is only logical that the next word on these problems be given to physical anthropology, which deals with what are, on the whole, the least mutable parts of man, namely, his body and skeleton.

The somatology of the Indians, which barely saw its beginnings in the time of Humboldt and Morton, has now advanced to such a degree that at least some important generalizations concerning the American aborigines are possible. We have now at our disposal for comparison, in American museums alone, upwards of 20,000 Indian crania and skeletons from, all parts of the continent, while several thousand similar specimens are contained in European collections. A considerable advance, particularly in North America, has also been made in studying the living natives. Unfortunately, we are much less advantageously situated in regard to comparative skeletal material as well as with respect to data on the living man from other parts of the world, particularly from those regions where other indications lead us to look for the origin of the Indian.

\section{THE FACTS IN THE CASE}

What can be stated in the light of present knowledge concerning the American native with a fair degree of positiveness is that:
1. There is no acceptable evidence, nor any probability, that man originated on this continent;

2. Man did not reach America until after attaining a development superior to that of late Pleistocene man in Europe, and after having undergone advanced and thorough stem, and even racial and tribal, differentiation; and

3. While man, since the peopling of the American continent was commenced, has developed numerous secondary, sub-racial, localized structural modifications, these modifications cannot yet be regarded as fixed, and in no important features have they obliterated the old type and sub-types of the people.

We are further in a position to state that, notwithstanding the various secondary physical modifications referred to, the American natives, barring the more distantly related Eskimo, present throughout the Western Hemisphere numerous important features in common, which mark them plainly as parts of one stem of humanity. These features are $:^{15}$

1. The color of the skin. The color of the Indian differs, according to localities, from dusky yellowish-white to that of solid chocolate, but the prevailing color is brown.

2. The hair of the Indian, as a rule, is black, medium coarse and straight; the beard is scanty, especially on the sides of the face, and it is never long. There is no hair on the body except in the axillae and on the pubis, and even there it is usually sparse.

3. The Indian is generally free from characteristic odor. His heart-beat is slow. His mental characteristics are everywhere much alike. The size of the head and of the brain cavity is comparable throughout, averaging somewhat less than that of white men and women of similar stature.

4. The eyes, as a rule, are dark brown in color, with dirty yellowish conjunctiva in adults, and the eye-slits show a prevailing tendency, more or less

1899, pp. 1-28: Hallock, Charles, "The Ancestors of the American Indigenes," Amer. Antiquarian, xxiv, No. 1, 1902, and the publications of the Jesup Expedition of the American Museum of Natural History, New York.

15 The remarks apply to the Indian not affected by sedentary habits and other conditions due to changed mode of life attending the process of civilization. 


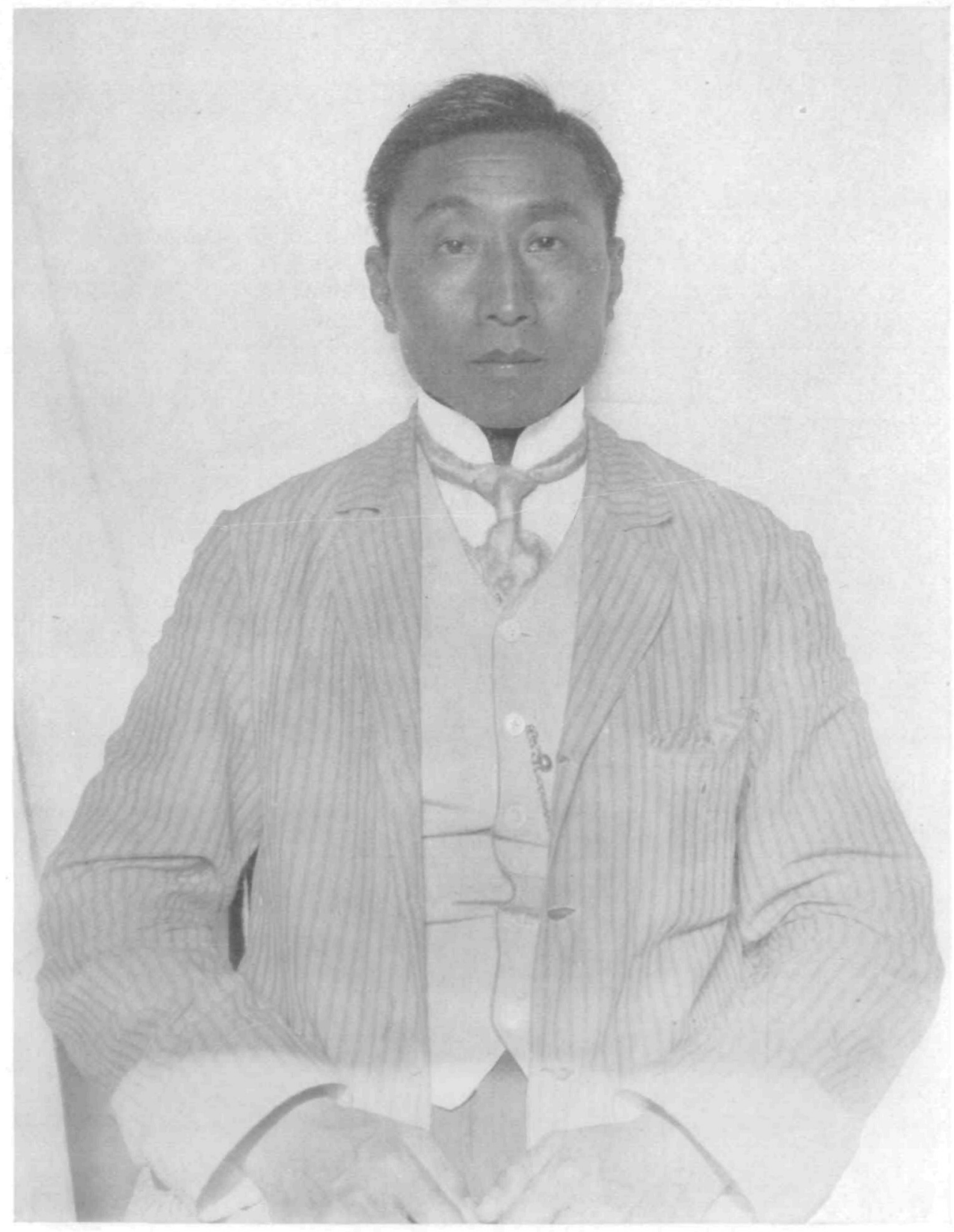

\section{A YOUNG MANCHU}

He would pass without the slightest difficulty for an Indian student at Haskell or Carlisle, Dr. Hrdlicka remarks. The nose is characteristic of the stock on both sides of the Pacific, being mesorhinic or moderately broad-not flat like that of a negro nor again thin like that of a Caucasian. (Fig. 18.) 


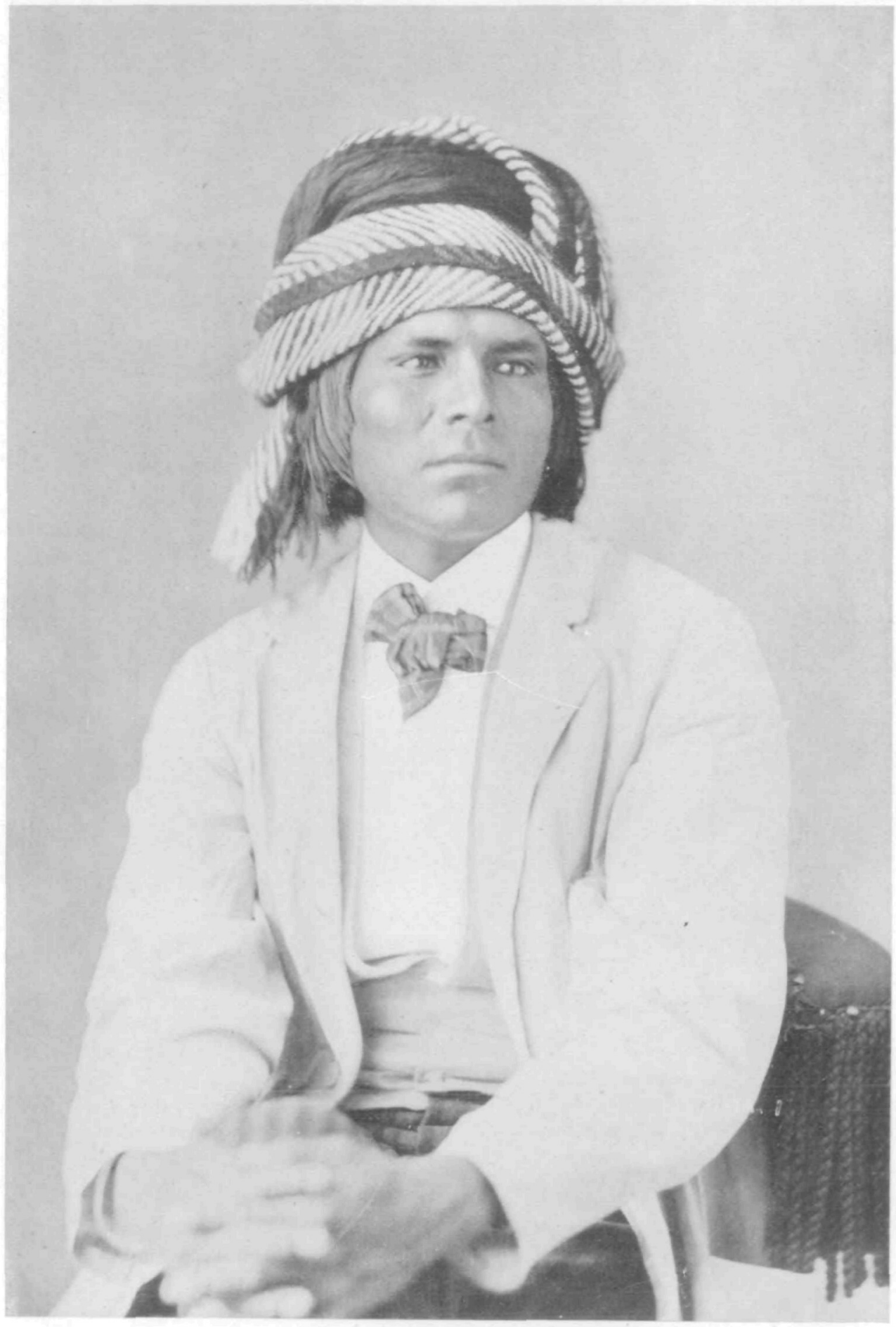

\section{PIMA INDIAN FROM ARIZONA}

With the headdress peculiar to some of his tribe, he would easily pass for an oriental. As Dr. Hrdlicka notes, the American Indian resembles the Polynesian quite as strongly as he often does the "Tartar" or Mongolian. In many of the .Iexican tribes the resemblance is still more striking. (Fig. 19.) 
noticeable in different tribes, to a slight upward slant, that is, the external canthi are frequently more or less higher than the internal.

5 . The nasal bridge is moderately to well developed, and the nose in the living, as well as the nasal aperture in the skull (barring individual and some localized exceptions), show medium or mesorhinic relative proportions. The malar regions are, as a rule, rather large or prominent.

\section{TEETH ARE CHARACTERISTIC.}

6. The mouth is generally fairly large, the lips average from medium to slightly fuller than in whites, and the lower facial region shows throughout a medium degree of prognathism, standing, like the relative proportions of the nose, about midway between those in the whites and those characteristic of the negroes. The chin is well developed, not seldom square. The teeth are of medium size when compared with those of primitive man in general, but perceptibly larger when contrasted with those of the cultured white American or European; the upper incisors of the Indian present an especially important feature; they are characteristically shovel-shaped, that is, deeply and peculiarly concave on the buccal side. The ears are rather large.

7. The neck, as a rule, is of only moderate length, and in health is never thin; the chest is somewhat deeper than in average whites; the breasts of the women are of medium size, and generally more or less conical in form. There is a complete absence of steatopygy; the lower limbs are less shapely and especially less full than in whites; the calf in the majority is small.

8. The hands and feet, as a rule, are of relatively moderate or even of small dimensions, and what is among the most important features distinguishing the Indian, the relative proportions of his forearms to arms and those of the distal parts of the lower limbs to the proximal (or, in the skeleton, the radiohumeral and tibio-femoral indices) are in general, throughout the two parts of the continent, of much the same average value, which value differs from that of both the whites and the negroes, standing again in an intermediary position.

This list of characteristics, which are, broadly speaking, shared by all American natives, could readily be extended, but the common features mentioned ought to be sufficient to make clear the fundamental unity of the Indians.

The question that necessarily follows is: "Which, among the different peoples of the globe, does the Indian as here characterized most resemble?" The answer, notwithstanding our imperfect knowledge, can be given quite conclusively. There is a great stem of humanity which embraces people ranging from yellowish-white to dark brown in color, with straight black hair, scanty beard, hairless body, brown, often more or less slanting eye, prevalently mesorhinic nose, medium alveolar prognathism, and in many other essential features much like the American native; and this stem, embracing several sub-types and many nationalities and tribes, occupies the eastern half of the Asiatic continent and a large part of Polynesia.

\section{CLOSE RELATIONSHIP.}

From the physical anthropologist's point of view everything indicates that the origin of the American Indian is to be sought among the yellowish-brown peoples mentioned. There are no two large branches of humanity on the globe that show closer fundamental physical relations.

But difficulties arise when we endeavor to assign the origin of the Indian to some particular branch of the yellowishbrown population. We find that he stands quite as closely related to some of the Malaysian peoples as to a part of the Tibetans, or some of the northeastern Asiatics. It is doubtless this fact that accounts for the hypotheses that attribute the derivation of the American Indians partly to the "Tartars" and partly to the Polynesians.

All that may be said on this occasion is that the circumstances point strongly to a coming, not strictly a migration, after the glacial period, and over land, ice, water, or by all these media combined, from north-eastern Asia, of 


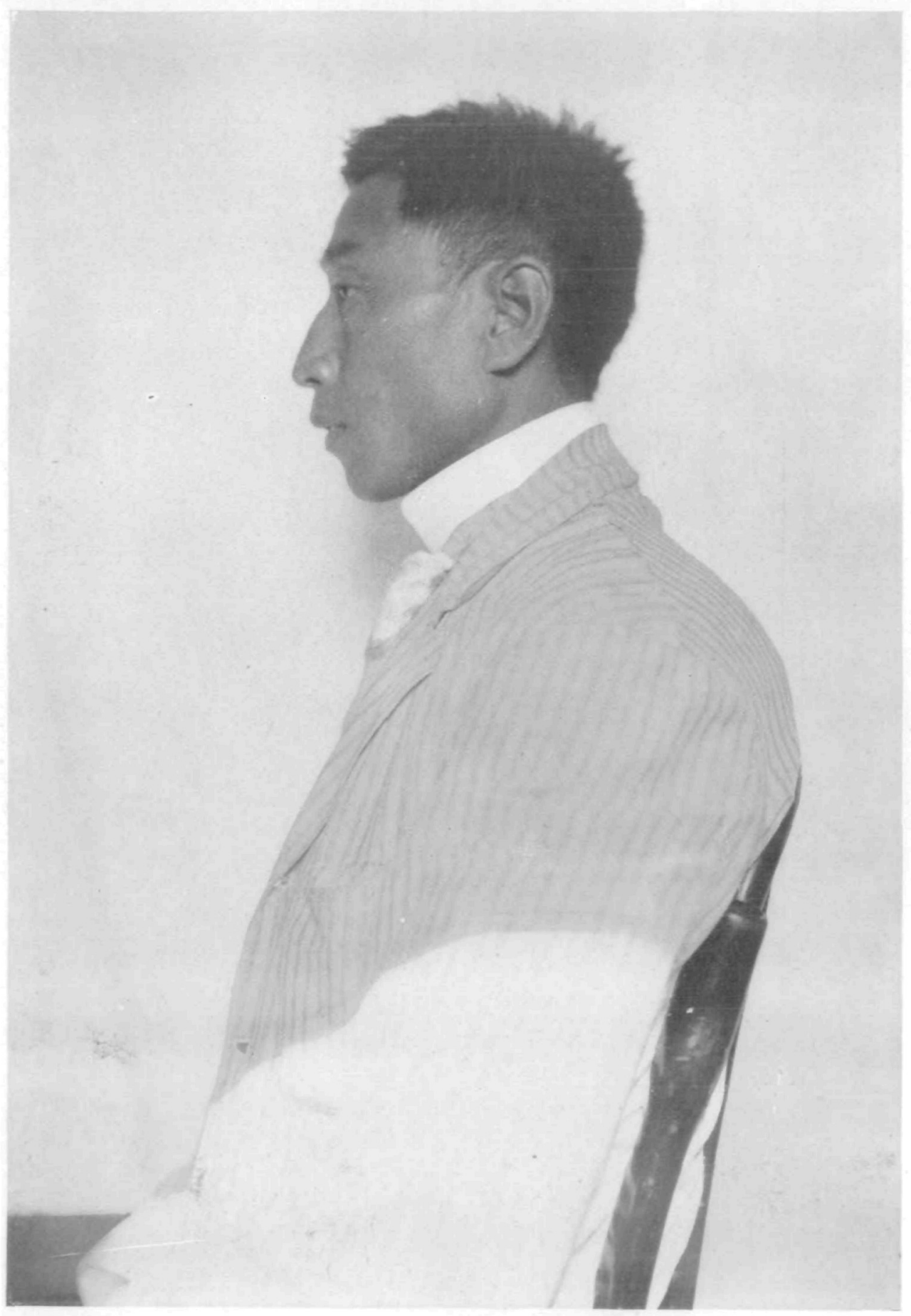

PROFILE OF YOUYG MANCHU

The same individual was shown full face in fig. 18. Compare his alveolar prognathism with " that of the American Indian in the next cut. The ear, it will be noted, is rather large,a racial characteristic of the Indian, also. The hair, coarse, black, and straight, is precisely like that of the American Indian. (Fig. 20.) 


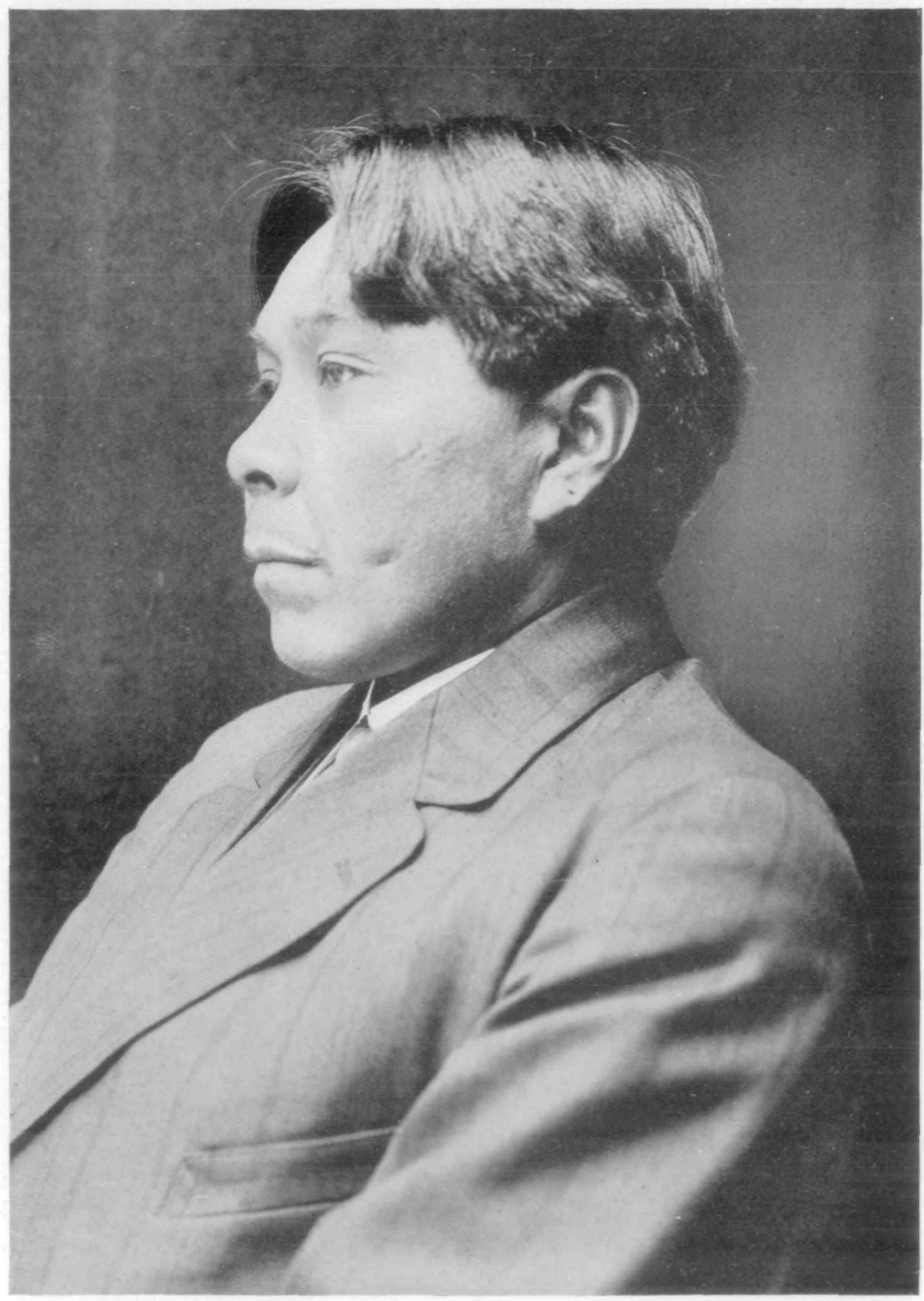

\section{A PUGeT SOUND INDIAN}

Skitswish tribe, Salisham stock. He illustrates the characteristic alveolar prognathism of the Indian-the slight projection of the teeth, altering the profile. The white race rarely shows this projection in such a degree, while in the negro race it is still more pronounced. (Fig. 21.) 
relatively small parties, overflows of the far eastern populations of that time, and to the peopling of America by the local multiplication of man thus introduced, to comings repeated probably nearly to the beginning of the historic period.

As to Polynesian migrations within the Pacific, such were, so far as can be determined, all relatively recent, having taken place when America doubtless had already a large population and had developed several native cultures. It is, however, probable that after spreading over the islands, small parties of Polynesians have accidentally reached America. If so, they may have modified in some respects the native culture; but physically, being radically like the people who received them (barring their probably more recent negro mixture), they would readily blend with the Indian and their progeny could not be distinguished. In a similar way small parties of whites may have probably reached the continent in the east. They, too, may have introduced some cultural modifications, but they would necessarily consist of men only and of parties small in number, which would in the course of time blend thoroughly with the Indian.

The conclusions, therefore, are: the American natives represent in the main a single stem or strain of people, one homotype; this stem is identical with that of the yellow-brown races of Asia and Polynesia; and the main immigration of the Americans has taken place, in the main, at least, gradually and by the northwestern route in the earlier part of the recent period, after man had reached a relatively high stage of physical development and multiple secondary differentiations. The immigration, in all probability, was a dribbling and prolonged overflow, likely due to pressure from behind, or want, and a search for better hunting and fishing ground $\approx$ in the direction where no resistance of man as yet existed. This was followed by multiplication, spread, and numerous minor differentiations of the people on the new, vast, and environmentally highly varied continent, by rapid differentiation of language due to isolation and other natural conditions, and by the development, on the basis of what was transported, of more or less localized American cultures. It is also probable that the western coast of America, within the last 2,000 years, was on more than one occasion reached by small parties of Polynesians, and that the eastern coast was similarly reached by small groups of whites, and that such parties may have locally influenced the culture of the Americans; but such accretions have nowhere, as far as we know today, modified the native population.

\section{Genetics and Government}

The great danger of democracy is that, more even than other forms of government, it may consider reforms too exclusively from the point of view of the immediate comfort of the individual, and may ignore the slow but irrevocable effect on the inborn character of future generations. All the more necessary is it that those who veriture to assume the heavy responsibility of attempting to legislate for democracy should understand the nature of the fundamental problems of race on which the future welfare of the nation depends. The time may come when a genealogical survey of the families of a nation will be recognized to be of greater value than a geological survey of the country they occupy.-W. C. D. and C. D. Whetham: Heredity and Society.

\section{Breeding for Energy}

In any scheme of eugenics, energy is the most important quality to favor; it is, as we have seen, the basis of living action, and it is eminently transmissible by descent.-Francis Galton: Inquiries into Human Faculty (1907). 